REFLEKSI HUKUM

Jurnal Ilmu Hukum
p-ISSN 2541-4984 | e-ISSN 2541-5417

Volume 3 Nomor 1, Oktober 2018, Halaman 33-48

DOI: https://doi.org/10.24246/jrh.2018.v3.i1.p33-48

Open access at: http://ejournal.uksw.edu/refleksihukum Penerbit: Fakultas Hukum Universitas Kristen Satya Wacana

\title{
MAHKAMAH KONSTITUSI SEBAGAI ELECTION COURT: REFLEKSI TEORETIS 1
}

\author{
Titon Slamet Kurnia \\ Fakultas Hukum Universitas Kristen Satya Wacana \\ Korespondensi: titon.kurnia@staff.uksw.edu
}

\begin{abstract}
Abstrak
Konstitusi Indonesia (UUD NRI 1945) memberikan kewenangan kepada Mahkamah Konstitusi untuk memutus perselisihan hasil pemilu. Secara teoretis, kewenangan ini menjadikan Mahkamah Konstitusi sebagai badan peradilan pemilu. Sesuai latar belakang tersebut, artikel ini menawarkan refleksi teoretis terhadap fungsi/peran Mahkamah Konstitusi sebagai election court. Adapun isu utamanya adalah refleksi teoretis berkenaan dengan ajudikasi. Teori yang ditawarkan di sini bersifat normatif karena klaimnya adalah tentang apa yang seyogianya dilakukan Mahkamah Konstitusi, bukan apa yang biasa dilakukan Mahkamah Konstitusi. Sebagai asas/prinsip, artikel ini berpendapat bahwa prudensialitas harus yang utama, sementara aktivisme yudisial adalah nomor dua. Teori ini untuk mengkritisi, dan kemudian mengkoreksi, praktik ajudikasi perselisihan atau sengketa pemilu oleh Mahkamah Konstitusi di masa lalu.
\end{abstract}

Kata Kunci: Mahkamah Konstitusi; Pemilu; Refleksi Teoretis.

\begin{abstract}
The Constitution of Indonesia (UUD NRI 1945) confers authority to the Constitutional Court to decide disputes on the results of general elections. Theoretically, this authority develops the Constitutional Court as the election court. According to this background, this article proposes a theoretical reflection over the Constitutional Court's role as the election court. The main issue is theoretical reflection on judging. The theory is normative because it claims about what should the Constitutional Court do instead of what did the Constitutional Court do. As the principle, it suggests prudentiality first and judicial activism second. This theory is to criticize, and then to correct, the Constitutional Court practices as the election court in the past.
\end{abstract}

Keywords: Constitutional Court; Election; Theoretical Reflection.

Artikel ini hasil revisi dari makalah berjudul "Ajudikasi Sengketa Pemilu oleh Mahkamah Konstitusi: Refleksi Teoretis" yang disampaikan pada Seminar Nasional dan FGD "Mewujudkan Pileg dan Pilpres Serentak yang Berintegritas" oleh Kepaniteraan dan Sekretariat Jenderal Mahkamah Konstitusi Republik Indonesia bekerja sama dengan Fakultas Hukum Universitas Kristen Satya Wacana. Salatiga, Sabtu, 20 Oktober, 2018. 


\section{PENDAHULUAN}

Pemilu adalah komitmen pada asas atau prinsip demokrasi dalam penyelenggaraan pemerintahan ${ }^{2}$ yang harus dijalankan dengan tunduk pada batasan-batasan hukum yang berlaku sebagai komitmen pada asas atau prinsip negara hukum. ${ }^{3}$ Sebagai proses kompetitif untuk memperebutkan suara rakyat (konstituen), para kontestan memiliki hak dan kewajiban. ${ }^{4}$ Dalam situasi demikian potensi sengketa pemilu menjadi keniscayaan, baik antar kontestan satu sama lain maupun antara kontestan dengan penyelenggara pemilu.

Hukum menyediakan mekanisme supaya sengketa demikian dapat diselesaikan melalui suatu putusan yang mengikat oleh pihak ketiga. Mahkamah Konstitusi adalah institusi, dalam penyelenggaraan pemilu di Indonesia, yang diberikan kewenangan konstitusional untuk melakukan ajudikasi atas sengketa dalam pemilu, khususnya, yang secara eksplisit, perselisihan hasil pemilihan umum. ${ }^{5}$ Fungsi dari kewenangan demikian yang dikonsepsikan di sini sebagai election court, yaitu badan peradilan yang diberikan kewenangan ajudikasi terhadap sengketa yang timbul dalam penyelenggaraan pemilu. Fungsi dan kewenangan demikian tentu saja menggariskan pemahaman konseptual tentang peran Mahkamah Konstitusi yang sangat vital terkait dengan aspirasi untuk pemilu yang harus tunduk pada batasan-batasan hukum yang berlaku.

Artikel ini tidak dimaksudkan untuk membahas aspek-aspek teknisyuridis berkaitan dengan proses ajudikasi sengketa pemilu oleh Mahkamah Konstitusi. Isu yang hendak didiskusikan di sini lebih umum, theoretical reflection on judging, dalam hal ini teoresasi terhadap partisipasi Mahkamah Konstitusi dalam penyelenggaraan pemilu, khususnya dalam ajudikasi terhadap sengketa pemilu dalam fungsinya sebagai election court. Pertanyaan inti untuk pembahasan adalah apa yang seyogianya dilakukan Mahkamah Konstitusi.

Atas pertanyaan tersebut maka fokus diskusi saya lebih bersifat normatif, tidak deskriptif. Itu artinya, dalam diskusi, saya akan berpendapat tentang "apa yang seyogianya dilakukan Mahkamah Konstitusi", bukan "apa yang biasa dilakukan Mahkamah Konstitusi". Peran yang seyogianya oleh Mahkamah Konstitusi ditujukan pada upaya agar pemilu dapat berjalan sesuai dengan batasan-batasan hukum yang berlaku, khususnya yang dalam batasan konstitusional dirumuskan menjadi norma atau kaidah "langsung, umum, bebas, rahasia, jujur dan adil" atau "luber-jurdil". 6

Vide Pasal 1 ayat (2) UUD NRI 1945.

Vide Pasal 1 ayat (3) UUD NRI 1945.

Kontestan di sini adalah calon anggota DPR, DPD, DPRD Provinsi, DPRD Kabupaten/Kota dan Calon Presiden/Wakil Presiden.

5 Vide Pasal 24C ayat (1) UUD NRI 1945.

$6 \quad$ Vide Pasal 22E ayat (1) UUD NRI 1945. Bandingkan dengan pendapat yudisial Mahkamah Konstitusi yang menyatakan: "Hakikat pemilihan umum, bukanlah semata-mata dalam rangka mencapai tujuan untuk mendapatkan dukungan dan legitimasi rakyat semata, tetapi pemilihan umum harus pula melalui prosedur dan tata cara yang ditentukan oleh hukum yang berlaku. Dalam demokrasi antara 
Pendapat hukum yang dikemukakan di sini sekaligus bersifat antisipatif terkait dengan peran yudisial Mahkamah Konstitusi yang seyogianya dalam penyelenggaraan pemilu legislatif dan pemilu presiden/wakil presiden serentak pada April 2019, baik bersifat ex ante maupun, nantinya, bersifat ex post, yaitu sebagai instrumen evaluasi atas capaian kinerja yudisial Mahkamah Konstitusi. Jika digambarkan, alur pembahasan artikel ini bergerak dari historis (past) ke futuristis (future). Itu artinya, pendapat tentang peran yang seyogianya dari Mahkamah Konstitusi dielaborasi berdasarkan pengalaman yang sudah terjadi dan pendapat tentang peran yang seyo-gianya tersebut dimaksudkan sebagai bentuk koreksi terhadap praktik yang ada, yaitu peran yang sudah terjadi atau dilakukan.

\section{PEMBAHASAN}

\section{Inovasi Yudisial Mahkamah Konstitusi dalam Ajudikasi Sengketa Pemilu}

Peran yudisial Mahkamah Konstitusi dalam ajudikasi sengketa pemilu sejatinya tidak kalah monumental jika dibandingkan dengan pengujian undang-undang. Sub-judul ini secara deskriptif akan menampilkan "inovasi" Mahkamah Konstitusi dalam ajudikasi sengketa pemilu yang berbentuk aktivitas judicial law-making. ${ }^{7}$ Aktivitas ini dapat positif atau negatif maknanya. Poin saya di sini adalah aspek negatifnya yang mungkin justru lebih besar karena dapat berdampak destruktif kepada institusi Mahkamah Konstitusi sendiri (dalam hal ini keterpercayaannya sebagai badan yudisial) atau, secara konsekuensialis, berdampak negatif terhadap "legitimasi" pemilunya sendiri. ${ }^{8}$ Walau dapat menghargai yang sudah dilakukan oleh Mahkamah Konstitusi, posisi saya adalah kritis (terutama untuk kasus yang akan datang).

Oleh karena itu, refleksi historis ini saya anggap sangat krusial sebagai pedoman ke depan, pada Pemilu 2019, supaya tidak secara gegabah diulang oleh Mahkamah Konstitusi (termasuk dengan versi yang lain). Sebagai badan yudisial yang memiliki nature inheren untuk mengadministrasikan keadilan dalam memberikan putusan atas suatu perkara, sudah sewajarnya jika Mahkamah Konstitusi dipercaya untuk menjalankan perannya itu secara leluasa. Hal ini sejatinya telah menjadi asas atau prinsip universal yang berlaku untuk badan yudisial yang disebut independent judiciary atau judicial independence. 9 Namun, sikap prudent adalah asas atau prinsip pertama (the first principle) dalam bagaimana Mahkamah Konstitusi seyogianya menjalankan independensi-

tujuan dan tata cara adalah dua sisi yang tidak bisa diabaikan. Prosedur dan tata cara justru untuk memberi jaminan tegaknya prinsip demokrasi yang memberi jaminan atas persamaan hak, kesetaraan dan kebebasan itu sendiri." Putusan No. 1/PHPU.PRES-XII/2014, 4149.

$7 \quad$ Aktivitas ini tidak hanya "create an individual legal norm (inter partes)," tetapi juga "creates a general legal norm”. Aharon Barak, 'On Society, Law and Judging' (2011) 47 Tulsa Law Review 297, 299.

8 Cf. Simon Butt, 'The Constitutional Court and Indonesian Electoral Law' (2016) 16 Australian Journal of Asian Law 1, 1-18.

9 Cf. Titon Slamet Kurnia, Mahkamah Konstitusi Republik Indonesia: Sang Penjaga HAM (The Guardian of Human Rights) (Penerbit PT. Alumni 2013) 73-85. 
nya itu sebagai badan yudisial. Inovasi Mahkamah Konstitusi memang dapat dimaklumi berdasarkan asas atau prinsip independensi yudisial, tetapi praktik seperti ini harus dalam posisi sebagai ultimum remedium atau upaya terakhir (the last resort).

\section{Ad 1. Kualitas Penyelenggaraan} Pemilu

Dalam praktiknya, Mahkamah Konstitusi tidak berpuas diri hanya bertindak sebagai "kalkulator" belaka, fokus pada sengketa atau perselisihan hasil pemilu dalam arti sempit sesuai kewenangan yang diberikan oleh konstitusi. ${ }^{10}$ Melalui pendekatan keadilan substantif Mahkamah Konstitusi memperluas yurisdiksi materialnya dengan mengintrodusir kaidah penyelenggaraan pemilu yang harus bebas dari praktik pelanggaran terstruktur, sistematis dan masif (pelanggaran TSM) lewat Putusan No. 41/PHPU.D-VI/2008 dengan Pemohon Khofifah Indar Parawansa dan Mudjiono serta Termohon KPUD Jawa Timur dalam sengketa Pilkada Provinsi Jawa Timur. Berdasarkan dalil tersebut Mahkamah Konstitusi menyatakan memiliki kewenangan untuk mengadili, tidak hanya perselisihan hasil pemilu, tetapi juga mengadili pelanggaran penyelenggaraan pemilu yang berakibat pada perolehan suara.
Dengan lugas dan gamblang Mahkamah Konstitusi menyatakan: "Mahkamah memandang perlu menciptakan terobosan guna memajukan demokrasi dan melepaskan diri dari kebiasaan praktik pelanggaran sistematis, yang terstruktur, dan masif seperti perkara a quo."11 Adapun argumen justifikasinya:

dalam memutus perselisihan hasil Pemilukada, Mahkamah tidak hanya menghitung kembali hasil penghitungan suara yang sebenarnya dari pemungutan suara tetapi juga harus menggali keadilan dengan menilai dan mengadili hasil penghitungan yang diperselisihkan, sebab kalau hanya menghitung dalam arti teknis-matematis sebenarnya bisa dilakukan penghitungan kembali oleh KPUD sendiri di bawah pengawasan Panwaslu dan/atau aparat kepolisian, atau cukup oleh pengadilan biasa. Oleh sebab itu, Mahkamah memahami bahwa meskipun menurut undangundang, yang dapat diadili oleh Mahkamah adalah hasil penghitungan suara, namun pelanggaran-pelanggaran yang menyebabkan terjadinya hasil penghitungan suara yang kemudian dipersengketakan itu harus pula dinilai untuk menegakkan keadilan. Hal ini sesuai dengan ketentuan Pasal 24 ayat (1) UUD 1945 yang berbunyi," Kekuasaan kehakiman merupakan kekuasaan yang merdeka untuk menyelenggarakan peradilan guna menegakkan hukum dan keadilan" dan Pasal 28D ayat (1) UUD 1945 yang berbunyi, "Setiap orang berhak atas pengakuan, jaminan, perlindungan, dan kepastian hukum yang adil serta perlakuan yang sama di hadapan hukum."12

10 Simon Butt, The Constitutional Court and Democracy in Indonesia (Brill 2015) 250; Pan Mohammad Faiz Kusuma Wijaya, The Role of Constitutional Court in Securing Constitutional Government in Indonesia (Ph.D Thesis, The University of Queensland 2016); Fritz Edward Siregar, Indonesian Constitutional Politics 2003-2013 (SJD Thesis, The University of New South Wales 2016).

11 Putusan Mahkamah Konstitusi Republik Indonesia Nomor 41/PHPU.D-VI/2008, Mahkamah Konstitusi, 28 November 2008, 129.

12 Ibid. Pendapat ini ditegaskan kembali dalam putusan perkara berbeda, yaitu Putusan No. 108109/PHPU.B-VII/2009: “a. Mahkamah memutus perkara berdasarkan UUD 1945 sesuai dengan alat bukti dan keyakinan hakim; b. bahwa Mahkamah dalam mengadili perselisihan hasil Pemilu, tidak 
Putusan ini adalah salah satu landmark-nya Mahkamah Konstitusi di bawah kepemimpinan Prof. Mahfud MD. (Mahfud Court). Di sini, sebagai election court, Mahkamah Konstitusi tidak semata-mata berorientasi hanya pada perhitungan hasil pemilu, tetapi juga kualitas (baca: konstitusionalitas) proses penyelenggaraan pemilu.

Prinsipnya, apa yang dilakukan Mahkamah Konstitusi sangat revolusioner, baik secara hukum maupun secara Teori Hukum (Teori Konstitusi), khususnya Teori Ajudikasi. Pendapat yudisial ini dapat disejajarkan dengan konstruksi dari pendapat yudisial Chief Justice John Marshall ketika mengintrodusir kewenangan Mahkamah Agung Amerika Serikat untuk menguji konstitusionalitas undangundang tanpa otorisasi eksplisit konstitusi ketika memutus kasus Marbury v. Madison (1803). Menilik pada hakikat kasusnya, yang dilakukan Mahkamah Konstitusi dalam kasus ini, jika dinilai secara kritis, akan sama penilaiannya dengan pendapat Alexander M. Bickel dalam menilai pendapat Marshall yang menyatakan:

Curiously enough, this power of judicial review, as it is called, does not derive from any explicit constitutional command. The authority to determine the meaning and application of a written constitution is nowhere defined or even mentioned in the document itself. This is not to say that the power of judicial review cannot be placed in the Constitution; merely that it cannot be found there. ${ }^{13}$

Kelebihan Marshall adalah menghadirkan apa yang tidak ada dalam teks konstitusi ke dalam hukum dari konstitusi dengan konstruksinya yang logis tentang posisi konstitusi sebagai hukum dan, sebagai hukum, konstitusi adalah hukum yang lebih tinggi dari undang-undang yang harus dijalankan oleh badan yudisial (hakim). ${ }^{14}$ Poin pendapat yang sama, mutatis mutandis, tentu saja dapat ditemukan dalam pendapat yudisial Mahkamah Konstitusi di mana, dalam sengketa pemilu, ranah kewenangan materialnya notabene sudah sangat limitatif ditentukan secara eksplisit oleh UUD NRI 1945 yaitu untuk memutus "perselisihan tentang hasil pemilihan umum". ${ }^{15}$ Tetapi yang terjadi, dengan logika yang menarik bahwa itu adalah nature dari badan yudisial, Mahkamah Konstitusi memperluas kewenangan materialnya dari soal perhitungan hasil perolehan suara dalam pemilu menjadi, termasuk, menilai kualitas penyelenggaraan pemilu karena untuk memperoleh hasil yang benar maka penyelenggaraannya ex ante juga harus benar secara inferensial dari ranah kekuasaannya sebagai kekuasaan yudisial atau kehakiman. ${ }^{16}$

hanya menghitung kembali hasil perhitungan suara, tetapi juga harus menggali keadilan dengan menilai dan mengadili hasil penghitungan suara an sich namun juga Mahkamah harus melihat pelanggaran-pelanggaran yang menyebabkan terjadinya perbedaan hasil penghitungan suara untuk menegakkan keadilan."

13 Alexander M. Bickel, The Least Dangerous Branch: The Supreme Court at the Bar of Politics (Yale University Press 1986) 1.

14 Robert J. Reinstein \& Mark C. Rahdert, 'Reconstructing Marbury' (2005) 57 Arkansas Law Review 729, 801-803.

15 Vide Pasal 24C ayat (1) UUD NRI 1945.

16 Vide Pasal 24 ayat (1) UUD NRI 1945. 
Masalahnya adalah, dengan mendalilkan terjadinya pelanggaran TSM, Mahkamah Konstitusi, walau bersifat kemungkinan, menyimpulkan pelanggaran tersebut menyebabkan terjadinya perbedaan hasil penghitungan suara. Itu artinya, secara kausalitas, perolehan suara yang diperoleh, dalam situasi terjadinya pelanggaran TSM, adalah akibat dari adanya pelanggaran tersebut. Sejatinya, kesimpulan demikian, hubungan kausal antara perolehan suara dengan pelanggaran TSM, logis, tetapi sangat sulit dibuktikan secara faktual. Oleh karena itu, pemungutan suara ulang sebagai preskripsi untuk situasi ini boleh dibilang dimotivasi oleh pertimbangan yang spekulatif (walaupun pelanggarannya sendiri secara terang benderang mampu dibuktikan, tetapi pengaruhnya terhadap perolehan suara tidak demikian adanya). Kecuali jika digunakan argumen bahwa pelanggaran TSM merupakan pelanggaran berat asas luber-jurdil sehingga atas dasar itu maka harus dilakukan pemungutan suara ulang karena asasnya pemungutan suara juga harus mencerminkan asas luber-jurdil. Argumen demikian menurut hemat saya jauh lebih memadai ketimbang praktik yang berkembang yang belum mampu membuktikan kebenaran kesimpulannya berdasarkan teori korespondensi.

\section{Ad 2. Noken}

Metode pemungutan suara dengan sistem noken terlahir berdasarkan pendapat yudisial Mahkamah Konstitusi dalam Putusan No. 47-81/PHPU.AVII/2009. Sejatinya, secara konseptual, yang dimaksud dengan sistem noken tersebut merujuk pada metode pemungutan suara yang digunakan di Papua, dalam hal ini Kabupaten Yahukimo. Metode tersebut adalah "kesepakatan warga" atau "aklamasi". Mahkamah Konstitusi memberikan pendapat yudisialnya sebagai berikut:

Menimbang bahwa Mahkamah
berpandangan, pemilihan umum di
Kabupaten Yahukimo tidak diseleng-
garakan berdasarkan peraturan
perundang-undangan yang berlaku (UU
10/2008 yang telah diubah terakhir
dengan Peraturan Pemerintah Pengganti
Undang-Undang Nomor 1 Tahun 2009
tentang Perubahan Atas Undang-
Undang Nomor 10 Tahun 2008 tentang
Pemilihan Umum Anggota Dewan
Perwakilan Rakyat, Dewan Perwakilan
Daerah, dan Dewan Perwakilan Rakyat
Daerah) karena tidak dengan cara
pencontrengan surat suara, melainkan
dengan "kesepakatan warga" atau
"aklamasi" dan hasilnya tetap
dimasukkan ke dalam rekapitulasi hasil
penghitungan suara yang dilaksanakan
padatanggal 6 Mei 2009 di KPU Provinsi
Papua. ${ }^{17}$.

Justifikasi untuk konstitusionalitas penerapan metode "kesepakatan warga" atau "aklamasi" tersebut adalah:

Menimbang bahwa Mahkamah dapat memahami dan menghargai nilai budaya yang hidup di kalangan masyarakat Papua yang khas dalam menyelenggarakan pemilihan umum dengan cara atau sistem "kesepakatan warga" atau "aklamasi". Mahkamah menerima cara pemilihan kolektif ("kesepakatan warga" atau "aklamasi") yang telah diterima masyarakat Kabupaten Yahukimo tersebut, karena jika dipaksakan pemilihan umum sesuai dengan peraturan perundang-undangan yang berlaku dikhawatirkan akan timbul konflik di antara kelompok-kelompok

17 Putusan Mahkamah Konstitusi Republik Indonesia Nomor 47-81/PHPU.A-VII/2009, Mahkamah Konstitusi, 7 Juni 2009, 46. 
masyarakat setempat. Mahkamah berpendapat, agar sebaiknya mereka tidak dilibatkan /dibawa ke sistem persaingan / perpecahan di dalam dan antar kelompok yang dapat mengganggu harmoni yang telah mereka hayati. 18

Catatan saya di sini ada dua. Pertama, teknis-yuridis. Kedua, substantif. Untuk catatan pada aspek teknisyuridis, Mahkamah Konstitusi tidak secara eksplisit menyatakan norma atau kaidah konstitusional sebagai dasar untuk pendapat yudisialnya. Dasar pendapat Mahkamah Konstitusi spekulatif, khawatir akan timbulnya konflik di antara kelompok-kelompok masyarakat setempat (jika berbeda pilihan politik). Di sini Mahkamah Konstitusi menggunakan pendekatan realisme dan mengorbankan tuntutan normal dari asas negara hukum supaya peraturan perundang-undangan yang berlaku dijalankan sebagaimana mestinya.

Untuk aspek substantif, Mahkamah Konstitusi sejatinya telah secara transparan mengabaikan konstitusi di mana untuk penyelenggaraan pemilu, termasuk pemungutan suaranya, konstitusi, UUD NRI 1945, telah menggariskan asasnya adalah "luberjurdil”. Metode pemungutan suara dengan jalan aklamasi seperti yang terjadi di Kabupaten Yahukimo jelas bertentangan dengan asas "luber-jurdil" sebagai asas konstitusi, tidak hanya prosedur atau mekanisme pemungutan suara yang ditetapkan dalam UndangUndang.

Walaupun tidak dinyatakan secara eksplisit sebagai norma atau kaidah dari pendapat yudisialnya, dalam kasus pengakuan konstitusionalitas "noken" (pemungutan suara dengan jalan kesepakatan warga atau aklamasi) Mahkamah Konstitusi secara tersirat mengamini hak masyarakat adat dalam pengambilan keputusan berdasarkan tradisinya sendiri19 dengan mengesampingkan asas atau prinsip pemilu yang universal yaitu luber, khususnya "bebas" dan "rahasia". Pendapat demikian sangat berbahaya karena tidak menempatkan konstitusi sebagai hukum yang supreme, tetapi Mahkamah Konstitusilah yang demikian, yang supreme.

Berbeda dengan yang pertama, inovasi kedua ini sangat sulit ditemukan nalarnya yang lurus karena jelas-jelas telah menabrak ketentuan konstitusi yang eksplisit. Inovasi pertama masih cukup logis karena merupakan hasil dari proses inferensi berdasarkan dasar konstitusional yang memungkinkan itu (terutama tentang hakikat kekuasaan yudisial). Pertanyaannya adalah bagaimana cara memahami kedua fenomena "inovasi" Mahkamah Konstitusi itu sebagai praktik yang normal oleh badan yudisial?

Dari sisi nature-nya, badan yudisial, di mana Mahkamah Konstitusi juga

\footnotetext{
18 Ibid.

19 Cf. Putusan No. 3/PHPU.D-10/2012 yang menyatakan kaidah: "pemungutan suara yang dilakukan dengan mekanisme dan tata cara hukum adat adalah sah. Penyelenggaraan Pemilu tidak boleh melanggar pengakuan dan perlindungan kesatuan masyarakat hukum adat beserta hak-hak tradisionalnya yang dijamin dalam Pasal 18B ayat (2) UUD 1945." Seperti diacu dalam Putusan Mahkamah Konstitusi Republik Indonesia Nomor 1/PHPU.PRES-XII/2014, Mahkamah Konstitusi, 8 Agustus 2014.
} 
adalah badan yudisial, dua posisi di atas sejatinya hal yang normal-normal saja untuk dilakukan berdasarkan asas independensi yudisial. Menurut Pamela Karlan, independensi yudisial mengandung makna: "Judges must be free from certain kinds of pressures or influences and free to envision and realize certain goals." 20 Lebih lanjut menurut Karlan, "Judges should be independent, not so much so that they can conceive goals and policies of their own and realize them, but so that they can enforce the goals and policies embodied in the Constitution and the laws enacted by democratic branches."21 Itu artinya, mendasarkan pendapat di atas, saya dapat menghargai yang telah dilakukan oleh Mahkamah Konstitusi, setidaknya karena independensinya sebagai badan yudisial ia dapat "enforce the goals and policies embodied in the Constitution and the laws enacted by democratic branches". Secara substantif, alasan yang dikemukakan oleh Mahkamah Konstitusi juga ada benarnya. Walaupun tentang dasar untuk proses penyimpulannya serta kesimpulannya sendiri saya dalam posisi yang sangat berbeda, khususnya menyangkut konstitusionalitas sistem noken. Isu teoretis utama dua kasus di atas, pelanggaran
TSM dan sistem noken, mewakili kelemahan penggunaan pendekatan realisme dalam ajudikasi oleh Mahkamah Konstitusi: kebenaran kesimpulan harus faktual, tidak cukup hanya rasional. 22

\section{Mahkamah Konstitusi dan Sengketa Pilpres 2014}

Pemilu 2019, khususnya pemilu presiden, berpotensi menjadi kasus sangat sulit yang akan dihadapi oleh Mahkamah Konstitusi. Oleh karena itu, tulisan ini akan melakukan refleksi ke belakang guna memahami kesulitan yang akan dihadapi tersebut. Kesulitan yang mungkin terjadi untuk Pemilu 2019 nanti khususnya akan timbul dari pemilu presiden yang rivalitasnya cenderung sangat keras dibandingkan dengan pemilu legislatifnya. Saya memprediksi salah satu faktor yang akan menyulitkan Mahkamah Konstitusi adalah pendapat yudisialnya sendiri sebelumnya, khususnya kaidah atau norma tentang kualitas penyelenggaraan pemilu yang melarang pelanggaran TSM dalam penyelenggaraan pemilu dan mengambil posisi untuk dapat mengadili pelanggaran ini termasuk dengan implikasinya mengadakan pemungutan suara ulang. Itu

20 Pamela Karlan, 'Judicial Independences' (2007) 95 Georgetown Law Journal 1041, 1042-1043.

21 Ibid., 1043. Cf. Aharon Barak, Op.Cit., 299-302.

22 Kelemahan seperti ini juga terjadi pada kasus sangat terkenal di Amerika Serikat yaitu Brown v. Board of Education di mana interpretasi konstitusi dilakukan dengan mengacu pada temuan penelitian psikologi sosial untuk memperkuat dasar empiris bagi keberlakuan equal educational opportunity doctrine. Berdasarkan hasil penelitian tersebut Mahkamah Agung Amerika Serikat menyimpulkan bahwa praktik segregasi sekolah publik atas dasar ras inkonstitusional karena bertentangan dengan equal protection clause walaupun dalam penyelenggaraan pendidikannya sendiri didasari asas separate but equal. Temuan dari penelitian psikologi sosialnya sendiri menyatakan orang-orang kulit hitam sangat dirugikan oleh praktik segregasi karena menimbulkan perasaan inferioritas. Oleh karena itu pengadilan menyimpulkan bahwa segregasi adalah praktik yang menimbulkan dampak inferioritas terhadap orang-orang kulit hitam. Kesimpulan demikian dipertanyakan karena dasar penyimpulannya di kemudian hari diketahui kurang representatif sampelnya. Michael Heise, "Brown v. Board of Education, Footnote 11, and Multidisciplinarity," (2005) 90 Cornell Law Review 279, 292293. 
artinya, pelanggaran TSM cenderung akan menjadi senjata bagi pemohon untuk membawa kasusnya ke Mahkamah Konstitusi walupun beban pembuktiannya sendiri tidaklah mudah.

Memahami kesulitan itu saya akan merefleksi sengketa pemilu presiden 2014 yang diputuskan oleh Mahkamah Konstitusi dalam Putusan No. 1/PHPU. PRES-XII/2014. Sebagai catatan awal, upaya pemohon, pasangan Prabowo Subianto dan Hatta Rajasa, membawa kasus ini ke Mahkamah Konstitusi sangat lemah dalam pembuktian dalildalilnya, khususnya untuk menggiring kesimpulan bahwa telah terjadi pelanggaran TSM dalam pemilu presiden. ${ }^{23}$ Tetapi dalam poin tertentu yang alasan hukum yang diajukan pemohon sesungguhnya cukup beralasan, antara lain terkait dengan kerugian pemohon akibat penerapan sistem noken di beberapa daerah di Papua.

Walaupun isu kerugian pada pihak pemohon karena penerapan sistem noken ini tidak signifikan dengan perolehan suara keseluruhan, karena dapat mengubah hasil akhir pemilu presiden itu sendiri, tetapi saya memberikan catatan kritis untuk penerapan sistem noken ini di mana seharusnya melalui Putusan No. 1/PHPU.PRES-XII/2014 Mahkamah Konstitusi melakukan overruling terhadap pendapat yudisialnya dalam Putusan No. 47-81/PHPU.A-VII/2009. Bentuk overruling yang seyogianya dilakukan adalah mempersempit penerapan sistem noken dengan mengecualikannya pada pemilu presiden karena daerah pemilihannya bersifat nasional.

Dalam Putusan No. 1/PHPU.PRESXII/2014, Mahkamah Konstitusi menyia-nyiakan kesempatan untuk melakukan rekonsiderasi posisi awal dari pendapatnya tentang konstitusionalitas penerapan metode pemungutan suara dengan jalan kesepakatan warga atau aklamasi (sistem noken). Pada poin ini, saya sepakat dengan posisi pemohon, bahwa penerapan sistem noken merugikan haknya sebagai peserta pemilu presiden. Jika Mahkamah Konstitusi sensitif dengan isu ini, meskipun pendapat yudisialnya tidak diberlakukan secara retroaktif karena asas praduga konstitusional, pendapat yudisial hasil overruling tersebut dapat menjadi kaidah untuk pemilu 2019 mendatang, khususnya sebatas untuk pemilu presiden.

Posisi Mahkamah Konstitusi tentang sistem noken sebagaimana dinyatakan kembali dalam Putusan No. 1/PHPU.PRES-XII/2014 pada asasnya menegaskan posisi awal dari konstitusionalitas sistem noken berdasarkan Putusan No. 47-81/PHPU.A-VII/2009, Putusan No. 19/PHPU.D-IX/2011, Putusan No. 3/PHPU.D-X/2012, Putusan No. 14/PHPU.D-XI/2013 dan Putusan No. $\quad$ 06-32/PHPU-DPD/XII/2014.24 Adapun untuk pembatasannya Mahkamah Konstitusi hanya menggariskan beberapa kaidah sebagai berikut. Pertama, harus diadministrasikan dengan baik mulai dari tingkat terbawah sampai di tingkat provinsi. Kedua, hanya dapat diakui di tempat-tempat yang selama ini

23 Simon Butt, The Constitutional Court ..., Op.Cit., 279.

24 Putusan No. 1/PHPU.PRES-XII/2014, 4182-4186. 
memang selalu melaksanakan sistem noken dan tidak boleh untuk tempattempat yang tidak pernah menggunakan sistem noken atau tidak boleh untuk tempat yang sudah tidak lagi menggunakan sistem noken. ${ }^{25}$

Ketimbang melakukan overruling, Mahkamah Konstitusi lebih memilih memberikan obiter dictum terkait dengan masa depan keberlangsungan sistem noken. Untuk itu Mahkamah Konstitusi menyatakan: "Mahkamah berpendirian bahwa penyelenggaraan Pemilu dengan didukung oleh seluruh pemangku kepentingan harus proaktif untuk mensosialisasikan dan menginternalisasikan sistem Pemilu yang dimuat oleh peraturan perundangundangan yang berlaku."26 Pendapat demikian sejatinya sangat klise karena bukan itu isu hukum yang sesungguhnya.

Isu utama dari mekanisme pemungutan suara berdasarkan sistem noken adalah aspek fairness-nya baik kepada pemilik hak suara yang notabene adalah individu warga negara maupun peserta pemilu itu sendiri. Ketiadaan asas bebas dan rahasia dalam sistem noken jelas menghalangi kemungkinan pemilih berpendapat berbeda dengan mayoritas pemilih yang lain. Itu artinya, pemilih di sini, si pemilik hak suara itu sendiri, maupun peserta pemilu sangat dirugikan oleh berlakunya sistem noken. Oleh karena itu, seperti saya sampaikan sebelumnya, saya setuju dengan posisi pemohon dalam Putusan No. 1/PHPU.PRESXII/2014 yang merasa dirugikan oleh mekanisme pemungutan suara dengan sistem noken. Patut disayangkan hal ini tidak menjadi bahan introspeksi oleh Mahkamah Konstitusi. Seyogianya, aspek konsekuensialis dari pendapat yudisialnya tentang konstitusionalitas sistem noken juga dipertimbangkan, terutama kemungkinan sistem ini merugikan si pemilih dan juga peserta pemilu. Itu artinya, meskipun upaya untuk menghargai tradisi merupakan hal baik, tetapi juga harus diperhitungkan pula konsekuensinya supaya tidak ada pihak-pihak yang dirugikan haknya oleh penerapan mekanisme tersebut.

\section{Peran Seyogianya Mahkamah Konstitusi dalam Mengawal Pemilu 2019}

Isu utama saat ini adalah pemilu legislatif dan pemilu presiden serentak tahun 2019 yang demokratis dan tunduk pada batasan-batasan hukum yang berlaku serta peranan Mahkamah Konstitusi di dalamnya. Secara kontekstual, Mahkamah Konstitusi hadir di bagian hilir dari proses penyelenggaraan pemilu, yaitu jika terjadi perselisihan hasil pemilihan umum (termasuk jika terjadi pelanggaran yang menyebabkan terjadinya perbedaan hasil penghitungan suara). Kehadiran Mahkamah Konstitusi tentu sangat penting maknanya. Dalam situasi rivalitas pasti akan muncul sengketa, dan sengketa tersebut wajib hukumnya untuk diselesaikan (diputuskan). Secara yuridis, peran Mahkamah Konstitusi dalam mengakhiri sengketa pemilu tentu akan menggaransi terwujudnya penyelenggaraan pemilu yang mampu merefleksi- 
kan demokrasi dan sekaligus kepatuhan proses demokratis tersebut kepada hukum (dan khususnya konstitusi).

Dalam Teori Ajudikasi, pilihan pendekatan yang biasa ditempuh oleh pengadilan dalam mengadili dan memutus perkara ada dua: judicial activism dan judicial self-restraint. Aharon Barak menjelaskan, judicial activism adalah "the judicial tendency conscious or unconscious - to achieve the proper balance between conflicting social values ... through change in the existing law ... or through creating new law that did not previously exist ..."27 Sebaliknya, judicial self-restraint adalah "the judicial tendency - conscious to achieve the proper balance between conflicting social values by preserving existing law rather than creating new law."28 Pada tataran aplikatif, Barak menjelaskan bagaimana aplikasi konsepsi teoretis tersebut sebagai berikut:

An acivist judge will take an expansive view of standing and a narrow view of non-justiciability. An activist judge will not hesitate to use dicta, will base his ruling with broad explanations ('maximization'), and will develop new measures and remedies to protect the rights he recognizes. A self-restrained judge will hesitate to employ dicta - with the exception of dicta in favor of selfrestraint - and will employ a narrow foundation for his ruling ('minimalism') and will avoid developing new means or remedies. ${ }^{29}$

Dengan parameter atau tolok ukur di atas, inovasi yudisial oleh Mahkamah Konstitusi dalam melaksanakan fungsinya sebagai election court jelas dapat dikatagorikan sebagai pilihan atas pendekatan judicial activism. Pilihan seperti ini tentu merupakan isu yang akan selalu relevan untuk terus menerus diperdebatkan, baik secara umum maupun untuk kasus-kasus tertentu atau spesifik.

Dalam penyelesaian hasil pemilu 2019, pilihan pendekatan yang seyogianya ditempuh Mahkamah Konstitusi menjadi isu sangat strategis untuk didiskusikan sejak dini dalam rangka prediktabilitas Mahkamah Konstitusi sebagai election court. Pemilu 2019 sangat sulit dan krusial bagi bangsa Indonesia karena beberapa sebab. Pertama, ini adalah pengalaman pertama ketika pemilu legislatif dan pemilu presiden dijalankan serentak. Kedua, pemilu diselenggarakan di bawah Presiden yang juga turut serta dalam "perebutan" kursi presiden (incumbent atau petahana). Ketiga, ketegangan politik pasca Pemilu Presiden 2014 yang terlihat belum mencair sampai sekarang.

Untuk terwujudnya aspirasi pemilu 2019 yang demokratis dan tunduk pada batasan-batasan hukum yang berlaku, peran Mahkamah Konstitusi sangat penting. Oleh karena itu, Mahkamah Konstitusi seyogianya sejak dini mulai memberikan sinyal-sinyal yang agak lebih transparan tentang posisi dari peran yang akan diambilnya sebagai gate keeper penyelenggaraan pemilu melalui ajudikasi sengketa atau perselisihan pemilu (legislatif maupun presiden), termasuk bagaimana posisi dari peran itu, harus menjadi bagian

\footnotetext{
27 Aharon Barak, The Judge in a Democracy (Princeton University Press 2006) 271.

28 Ibid.

$29 \quad$ Ibid., 277.
} 
dari debat-debat publik mulai dari sekarang. Inilah isu utama yang hendak saya jawab melalui tulisan ini.

Untuk peran tersebut saya supaya Mahkamah Konstitusi seyogianya menempuh pendekatan dalam ajudikasi yang dipopulerkan oleh Alexander M. Bickel dengan istilah atau konsep "passive virtues" yang notabene merupakan varian dari pendekatan judicial selfrestraint, ketimbang pendekatan judicial activism. Isu utama dari konsep passive virtues adalah menjawab tentang "the timing and limits of the judicial function" 30 atau berkaitan dengan "the wide area of choice open to the Court in deciding whether, when, and how much to adjudicate."31 Pendekatan passive virtues memiliki karakter: "prudential..., but they should not be predilectional, sentimental, or irrational." 32 Poin utamanya adalah menghindari intervensi oleh badan yudisial ke dalam proses demokratis (meskipun badan yudisial sendiri mampu memberikan pengaruh di dalamnya): "None of the devices for avoiding adjudication work any binding interference with the democratic process, though the Court's prestige and the quality of its principles, its reasoning and its rhetoric, may make it a persuasive influence."33

Posisi ini saya tawarkan khususnya jika terkait dengan permintaan pemohon kepada Mahkamah Konstitusi untuk memberikan equitable relief atas alasan ex aequo et bono. Basis dari pendekatan ini adalah Mahkamah Konstitusi harus mengutamakan asas prudensialitas dalam menjalankan fungsi yudisialnya, termasuk meskipun menjalankan fungsi tersebut dalam koridor asas independensi yudisial itu sendiri. Itu artinya independensi yudisial harus dijalankan secara prudent oleh Mahkamah Konstitusi dengan tidak mudah menjatuhkan putusan yang bersifat diskresioner. Sikap prudent tersebut hendaknya memperhitungkan kemungkinan tentang dampak yang mungkin timbul dari putusannya, sehingga jika negatif maka Mahkamah Konstitusi harus menghindarinya.

Pertanyaannya adalah mengapa posisi ini? Saya tidak dapat membayangkan jika akhirnya Mahkamah Konstitusi masih melakukan "akrobat hukum" seperti saya jelaskan sebelumnya. "Akrobat hukum" seperti itu seyogianya hanya akan ditempuh sebagai upaya terakhir, the last resort. Jika cara-cara lain masih memungkinkan, berdasarkan pertimbangan prudensialitas, Mahkamah Konstitusi seyogianya menempuh posisi "passive virtues". Itu artinya, dalam menjalankan fungsi yudisialnya dalam menyelesaikan sengketa pemilu, Mahkamah Konstitusi tidak perlu bersikap heroik. ${ }^{34}$

Menurut Stefanus Hendrianto, konsep yang lebih spesifik dari passive virtues adalah "prudential-minimalist model". Menurut Hendrianto, passive virtues sebagai judicial self-restraint

30 Alexander M. Bickel, 'The Supreme Court 1960 Term: Foreword: Passive Virtues' (1961) 75 Harvard Law Review 40, 42.

Ibid., 79.

Ibid.

Ibid.

Cf. Stefanus Hendrianto, Law and Politics of Constitutional Courts: Indonesia and the Search for Judicial Heroes (Routledge 2018) 13-17. Hendrianto merumuskan kerangka konseptual untuk konsep judicial heroes dengan konsepsi yang "menyerupai” konsep judicial activism. 
mengandung pra-kondisi: "First, judges make a strategic choice to decide only relatively 'safe' or routine cases rather than politically charged cases about which elected politicians care deeply. Second, judges can adopt a general norm of issuing cautious, measured judgments rather than bold, provocative rulings." 35 Sementara prudential-minimalist adalah "court's engagement in judicial deferral" dengan kecenderungan badan yudisial untuk "defer to elected political branches of government and minimize the disruption or damage caused by courts' decisions." 36

Intinya, dalam menjalankan peran atau fungsi yudisialnya, badan yudisial harus menghindari timbulnya kontroversi dengan badan-badan pemerintahan demokratis. Itu artinya, aplikasi praktisnya adalah kombinasi antara "ambitious interpretations of the constitution with the willingness to recognize the merits of deferring to political judgments about the constitution." 37 Untuk praktik prudential -minimalist Hendrianto mencontohkan pendekatan Chief Justice John Marshall dalam kasus Marbury v. Madison: "Marshall's decision in Marbury was quite deft; on the one hand, he inserted a new constitutional doctrine that the interpretation and enforcement of the Constitution are the province of the judiciary and, ultimately, the Supreme Court. On the other hand, he avoided a confrontation with the Jefferson administration by refusing to issue the writ of mandamus against Madison." 38

Jika disimpulkan, prudentialminimalist versi Hendrianto lebih mengutamakan peranan yang besar dari hakim dalam mengelaborasi "hukum-nya", tetapi tidak pada hasil akhir kasusnya, dalam hal ini petitum dari perkara. Pada poin ini memang nampak perbedaan antara passive virtue dengan prudential-minimalist. Akan tetapi, apapun itu, perhatian utama saya lebih tertuju pada peranan Mahkamah Konstitusi yang tidak perlu terlalu ambisius seperti posisi yang diambil ketika mengembangkan pendekatan keadilan substantif tentang kualitas penyelenggaraan pemilu.

Lebih jauh lagi, background sebagai pra-pemahaman untuk sengketa pemilu juga seyogianya menjadi perhatian, terutama ketika kontestan pemilu meminta kepada Mahkamah Konstitusi untuk memutus sesuai kebijakannya secara ex aequo et bono. Tentu Mahkamah Konstitusi juga tidak akan gegabah. Tetapi poin utama saya lebih dari itu bahwa dari awal sikap prudent harus lebih mengemuka. Untuk itu, pemahaman teoretis tentang konsepsi equitable relief sendiri perlu diperhatikan. Seharusnya, asasnya, tidak setiap orang dapat begitu saja meminta equitable relief. ${ }^{39}$. Untuk mengajukan equitable relief, pihaknya harus, sebagai syarat a priori, "bertangan bersih" (clean hands doctrine). A contrario, unclean hands, tidak patut meminta atau

Ibid., 26.

Ibid.

Ibid., 29.

Ibid., 28.

T. Leigh Anenson, 'Announcing the 'Clean Hands' Doctrine' (2018) 51 UC Davis Law Review 1827, $1837-1847$. 
mengajukan equitable relief.40 Alasannya: "allowing a plaintiff with unclean hands to recover in an action creates doubts as to the justice provided by the judicial system." 41 Sementara equitable relief ini memberikan perlindungan kepada the clean hands dengan alasan: "promotes justice by preventing 'a wrongdoer enjoying the fruits of his (or her) transgression'."42 Pelajaran demikian rupanya kurang begitu kita perhatikan sehingga kesannya seolaholah pihak bebas meminta equitable relief kepada pengadilan supaya memutuskan berdasarkan pertimbangan "keadilan dan kepatutan" (ex aequo et bono).

Dalam pengamatan saya, pendekatan keadilan substantif yang diterapkan Mahkamah Konstitusi, dengan kecenderungan mengarah menjadi praktik judicial activism dalam ajudikasi sengketa pemilu terlalu ambisius. Berdasarkan penjelasan di atas maka pertanyaan reflektif saya sangat sederhana: Ketika "memberikan keadilan", apakah Mahkamah Konstitusi sungguh sangat yakin telah memberikannya kepada pihak yang bertangan bersih, tidak yang sebaliknya? Model kontestasi pemilu kita sangat sulit untuk dipahami karena segala cara dihalalkan untuk menjadi pemenang; semua pihak sangat terbuka memainkan strategi "bad cop" dan "good cop" sekaligus. Oleh karena itu, masuknya Mahkamah Konstitusi terlalu jauh ke dalam perkara, dengan tingkat kesulitan sangat tinggi dalam proses pembuktian, berpotensi berdampak negatif pada akurasi putusan yang dihasilkan. Ini terbukti dari komentar kritis Simon Butt terhadap "body of case law" Mahkamah Konstitusi dalam isu electoral law sebagai berikut: "the Court's electoral jurisprudence is highly problematic, riddled with poorly reasoned and inconsistent legal arguments, skewed approaches to constitutional interpretation, and undesirable side effects. Indeed, it might be argued that, in some respects at least, the Court's decisions have done more to harm democratic practice than improve it." 43

Poin utama saya di sini adalah saya ingin supaya "kewarasan" Mahkamah Konstitusi tetap terjaga untuk melindungi marwahnya sebagai "the guardian of democracy" dalam proses politik elektoral yang pastinya penuh dengan "ketidakwarasan" (khususnya dalam pemilu presiden). Posisi saya sendiri bersifat kondisional karena untuk pendekatan demikian seyogianya ada dukungan yang kuat oleh institusiinstitusi penyelenggara pemilu yang lain sesuai dengan ranah kewenangannya masing-masing yang diberikan oleh hukum. Itu artinya, mereka, sesuai dengan kewenangannya, seyogianya mampu menyelesaikan masalahmasalah dalam penyelenggaraan pemilu yang krusial yang berada di bawah yurisdiksinya. Hal ini akan meringankan beban yang harus ditanggung oleh Mahkamah Konstitusi, termasuk untuk menjauhkan Mahkamah Konstitusi dari

40 T. Leigh Anenson, 'Announcing the 'Clean Hands' Doctrine' (2018) 51 UC Davis Law Review 1827, 1837-1847.

$41 \quad$ Ibid., 1843.

$42 \quad$ Ibid., 1845.

43 Simon Butt, 'The Constitutional Court ...,' Op. Cit., 1. 
inisiatif guna melakukan "akrobat hukum". Jika pra-kondisi ini terjadi, semua sub-sistem penyelenggara pemilu, terutama sub-sistem penyelesaian pelanggaran-pelanggaran pemilu bekerja optimal, perkara yang harusnya diproses oleh Mahkamah Konstitusi adalah perkara yang memang merupakan yurisdiksi material orisinalnya sesuai UUD NRI 1945, yaitu "perselisihan hasil pemilihan umum".

Apakah itu artinya saya mengabaikan kemungkinan penerapan pendekatan judicial activism? Pendekatan ini dapat dilakukan jika didukung oleh insentif sangat memadai dan dalam posisi sebagai the last resort, khususnya, dalam rangka equitable relief, untuk memberikan perlindungan kepada "the clean hands", bukan yang lain.

\section{PENUTUP}

Mahkamah Konstitusi adalah institusi paling bertanggung jawab di bagian hilir dalam menjawab isu penyelenggaraan pemilu yang tunduk secara konsisten pada pembatasan hukum. Menjawab pertanyaan atau isu tentang fungsi atau peran institusional yang seyogianya dilakukan Mahkamah Konstitusi saya berpendapat bahwa prudensialitas adalah asasnya. Fungsi atau peran institusional sebagai election court seyogianya dijalankan secara prudent oleh Mahkamah Konstitusi.

Dalam proses politik yang mungkin akan penuh "kegilaan" Mahkamah Konstitusi harus menjadi satu-satunya institusi yang mampu menjaga "kewarasan"-nya, yaitu sebagai badan yudisial yang fungsi atau ranah kekuasaannya, kekuasaan yudisial atau judicial power, adalah 'to decide 'cases' and 'controversies' in conformity with law and by the methods established by the usages and principles of law," 44 tidak yang lain-lain. Jika batasan ini tidak mampu dipenuhi oleh Mahkamah Konstitusi saya khawatir pemilu yang ideal menjadi sulit diwujudkan. Dari perspektif ini pula saya mengajukan kritik atas pendekatan judicial activism supaya seyogianya tidak lagi dilakukan oleh Mahkamah Konstitusi secara tidak prudent.

\section{DAFTAR BACAAN}

\section{Buku}

Barak, A., The Judge in a Democracy (Princeton University Press 2006).

Bickel, Alexander M., The Least Dangerous Branch: The Supreme Court at the Bar of Politics (Yale University Press 1986).

Butt, S., The Constitutional Court and Democracy in Indonesia (Brill 2015).

Corwin, Edward S., The Constitution and What It Means Today (Princeton University Press 1978).

Hendrianto, S., Law and Politics of Constitutional Courts: Indonesia and the Search for Judicial Heroes (Routledge 2018).

Kurnia, Titon S., Mahkamah Konstitusi Republik Indonesia: Sang Penjaga

44 Prentis v. Atl. Coast Line Co. (1908), Muskrat v. U.S. (1911) dan Securities \& Exc. Com'n v. Medical Com. for Human Rights (1972). Edward S. Corwin, The Constitution and What It Means Today (Princeton University Press 1978) 204. 
HAM (The Guardian of Human Rights) (PT. Alumni 2013).

\section{Artikel Jurnal}

Anenson, T. L., 'Announcing the 'Clean Hands' Doctrine’ (2018) 51 UC Davis Law Review.

Barak, A., 'On Society, Law and Judging' (2011) 47 Tulsa Law Review.

Bickel, Alexander M., 'The Supreme Court 1960 Term: Foreword: Passive Virtues' (1961) 75 Harvard Law Review.

Butt, S., 'The Constitutional Court and Indonesian Electoral Law' (2016) 16 Australian Journal of Asian Law.

Heise, M., 'Brown v. Board of Education, Footnote 11, and Multidisciplinarity’ (2005) 90 Cornell Law Review.

Karlan, P., 'Judicial Independences' (2007) 95 Georgetown Law Journal.

Reinstein, Robert J., and Mark C. R., 'Reconstructing Marbury' (2005) 57 Arkansas Law Review.

\section{Tesis dan Disertasi}

Siregar, Fritz E., Indonesian Constitutional Politics 2003-2013 (SJD Thesis, The University of New South Wales 2016).

Wijaya, Pan Mohammad Faiz K., The Role of Constitutional Court in Securing Constitutional Government in Indonesia (Ph.D Thesis, The University of Queensland 2016).

\section{Putusan Pengadilan}

Putusan Mahkamah Konstitusi Republik Indonesia Nomor 41/PHPU.DVI/2008.
Putusan Mahkamah Konstitusi Republik Indonesia Nomor 4781/PHPU.A-VII/2009.

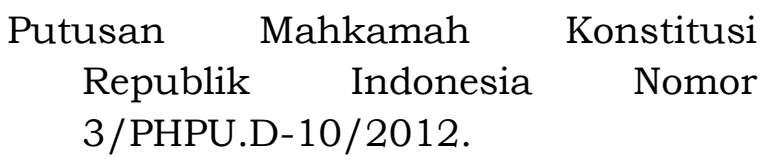

Putusan Mahkamah Konstitusi

Republik Indonesia Nomor 1/PHPU.PRES-XII/2014.

\section{Peraturan Perundang-Undangan}

Undang-Undang Dasar Negara Republik Indonesia Tahun 1945. 